Egyptian Journal of Aquatic Biology \& Fisheries

Zoology Department, Faculty of Science,

Ain Shams University, Cairo, Egypt.

ISSN $1110-6131$

Vol. 24(1): $65-81$ (2020)

www.ejabf.journals.ekb.eg

\title{
Quality assessment of water along Suez Freshwater Canal and drinking water in Suez Governorate, Egypt
}

\author{
Elham M. Ali ${ }^{1, *}$, Shenouda R. Falts ${ }^{2}$, Abdel-Hamied M. Rasmey ${ }^{2}$ \\ 1- Department of Aquatic Environment, Faculty of Fish Resources, Suez University, Egypt. \\ 2- Botany and Microbiology Department, Faculty of Science, Suez University, Suez, Egypt. \\ "Corresponding author: elhamali201212@gmail.com
}

\section{ARTICLE INFO}

\section{Article History:}

Received: Oct. 27, 2019

Accepted: Dec. 27, 2019

Online: Jan. 2020

Keywords:

Phytoplankton

Chlorophyll-a

Physico-chemical

Water quality

Water treatment

\section{ABSTRACT}

The current study aims to assess the quality of water along Suez Freshwater Canal as well as to evaluate the efficiency of treatment prior reaching the benifeshries. For this aim, water samples were collected for analyse over four seasons from December 2017 to November 2018 at six sites covering the Suez Freshwater Canal situated within the boundary of Suez city. Physico-chemical attributes and phytoplankton community structure were determined both at temporal and spatial scales. A total of 54 genera, 106 species were identified, which belong to Chlorophyta (27 genera, 51 species), Bacillariophyta (11 genera, 30 species), Cyanophyta (10 genera, 16 species), Euglenophyta (3 genera, 4 species), Cryptophyta (1 genus, 3 species), Crysophyta (1 genus, 1 species) and Dinophyta (1 genus, 1 species). Phytoplankton density estimates were greatest during the spring season, lower during the summer season, extremely lower during the winter season, and the lowest density during the autumn season $\left(160 \times 10^{5}\right.$ cells $/$, $133 \times 10^{5}$ cells $/ 1,89 \times 10^{5}$ cells $/ 1$ and $50 \times 10^{5}$ cells/l, respectively). This may reflect the relatively high polluted status of the Suez Freshwater Canal especially in spring. we have to add some results/indications about physicochemical attributes.

\section{INTRODUCTION}

The Nile River is one of the oldest and longest rivers worldwide with extent length of about 6.695 kilometers (NBI, 2016), it is running from Ethiopia at the south to Egypt passing through 10 countries. These countries are Uganda, Kenya, Tanzania, Rwanda, Burundi, DR Congo, Zaire, Ethiopia, Sudan and Egypt. The Nile is considered as the basic source for water for most of these countries including Egypt, however it represent a small part of water resources for others, such as the DR Congo (Karyabwite, 2000). The Nile River runs about $950 \mathrm{~km}$ from the Aswan High Dam to Cairo. Then it is divided into two branches: Rashid and Damietta, and at the end it reaches the Mediterranean Sea. On his long journey in Egypt, the Nile creates many fertile green valleys (Shalloof and El-Far, 2017). Uncontrolled discharging of waste effluents in the River Nile will cause negative health impacts on the consumers at the long term (Ibrahim et al., 2009). There is a clear decline in water quality where the Nile downstream at Rosetta and Damietta branches (Abdel-Aal, 2006). One of the most problems facing Egypt now is the urban and rural population increase that needs access to drinking water and sewage networks. Unfortunately, many rural families 
resort to getting rid of their waste through canals and water drains (Rawway et al., 2016). Discharge of the sewage into the river lead to water deterioration and eutrophication of its quality (Sukumaran, 2002).

The main supply of drinking water for Suez city is the Suez Freshwater Canal which extending from the Ismailia Canal. Ismailia Canal is constructed during the period 1858 1863 to provide drinking water to the workers during the digging processes of The Suez Canal. Ismailia Canal receives a lot of wastes that come from the petroleum, petrogas, iron industries, agricultural drains and untreated urban municipal which all deteriorates the water quality of the canal (Geriesh et al., 2008; Stahl et al., 2009 and Youssef et al., 2010). AWC (2009) reported a decline in water quality due to insufficient industrial and municipal wastewater treatment systems, agricultural drainage water and fast growth of urbanization. It is reported that the River Nile receive wastewater from 124 sources, 57 are industrial and the others are from agricultural sources (NWRC, 2000). The most important risks facing Egypt is the shortage of the Nile River level, especially after the completion of the construction of the Ethiopia Dam and the start of the stage of filling the reservoir with the waters of the Nile River (Abdel-Satar et al., 2017).

The bottom and sediments of rivers are considered a natural sponge that attracts most of the organic and inorganic pollutants in their content, but sometimes this bottom is a secondary source of pollution to the water ecosystem because it contains dangerous pollutants and heavy metals with high concentrations (Mostafa et al., 2019). There are several methods by which toxic heavy metals can be eliminated such as reverse osmosis, ion exchange and adsorption (Rashed et al., 2019). Water chemical analysis is a perfect indication of chemical quality of the Nile water but not indicator for the ecological state (Barbour and Yoder, 2000 and Karr et al., 2000). In addition, biological analysis could be also used as a good indicator of the ecological quality of the Nile water (Stevenson and Pan, 1999). The advantage of the biological analysis is that it identifies the organism and species in the water sample which responsible to pollution, but it does not present numerical basis compare to physical and chemical methods (Azamuddin Arsad et al., 2012).

Phytoplankton can be a reflective mirror of the quality of the water ecosystem (Ali and Khairy, 2012; Ali and Khairy, 2016). There are many biological properties that can be measured as system biodiversity and species richness, while others refer to the source of water pollution (Ali and El Shehawy, 2017). Freshwater phytoplankton are rapidly affected by any change in their ecosystem, so its species are good indicative of water quality (Bellinger and Sigee, 2015). Algae are growing on rivers, lakes, streams, ponds and oceans (Graham and Wilcox, 2000 and Wehr, 2003). Studies the algal abundance density, distribution, composition, diversity and physic-chemical factors of its habitat is very important to detect the biological content and the trophic status of the water body (Barbour et al., 1999; Chaturvedi et al., 1999 and Townsend et al., 2000). Algal communities used as useful indicator in the biomonitoring of river and stream ecosystems to detect the water quality problems (Clark et al., 2003 and Hill et al., 2000). The seasonal variation in the composition and abundance of phytoplankton is affected by many factors as nutrients, temperature, light and metabolites of plants (Agrawal, 1999). On occasion, the normal annual cycle of phytoplankton is changed because of the excessive growth of some species (Vaulot, 2001). Human activities as domestic and agricultural wastes also animals and birds urination are responsible for direct contamination of the River Nile. This study is aiming to assess the water quality along the Suez Freshwater 
Canal using some physicochemical characterization as well as biological evaluation during four seasons.

\section{MATERIALS AND METHODS}

\section{Samples collection}

Six sampling sites were selected along the Suez Freshwater Canal from Suez Governorate to Ismailia Governorate in order to cover different environmental conditions of the canal. A total of 44 water samples were collected including 32 (four for each of sites II-V and 12 from site I) samples from Suez Freshwater Canal and 12 samples from Suez water treatment plant. The samples were collected once monthly in the morning from 8-10 am and the samples along the Suez Freshwater Canal sites I, II, III, IV, V and VI (Table 1 and Fig. 1) were collected seasonally from December 2017 to November 2018.

Table 1: Positions and specifications of sampling sites.

\begin{tabular}{lcccl}
\hline Sites & Code & Latitude & Longitude & \multicolumn{1}{c}{ Specifications } \\
\hline Site $\mathbf{1}$ & S I & 29.9834540 & 32.5498910 & $\begin{array}{l}\text { El Hawes, Intake of Suez water } \\
\text { treatment plant }\end{array}$ \\
Site 2 & S II & 30.1697915 & 32.5444681 & El Shalofa \\
Site 3 & S III & 30.2369888 & 32.4240265 & Kabrit \\
Site 4 & S IV & 30.3472870 & 32.2908756 & Fayed \\
Site 5 & S V & 30.4701559 & 32.3261269 & Sarabium \\
Site 6 & S VI & 30.5699882 & 32.2457099 & Abu Atwa, near the intake of Ismailia \\
\end{tabular}

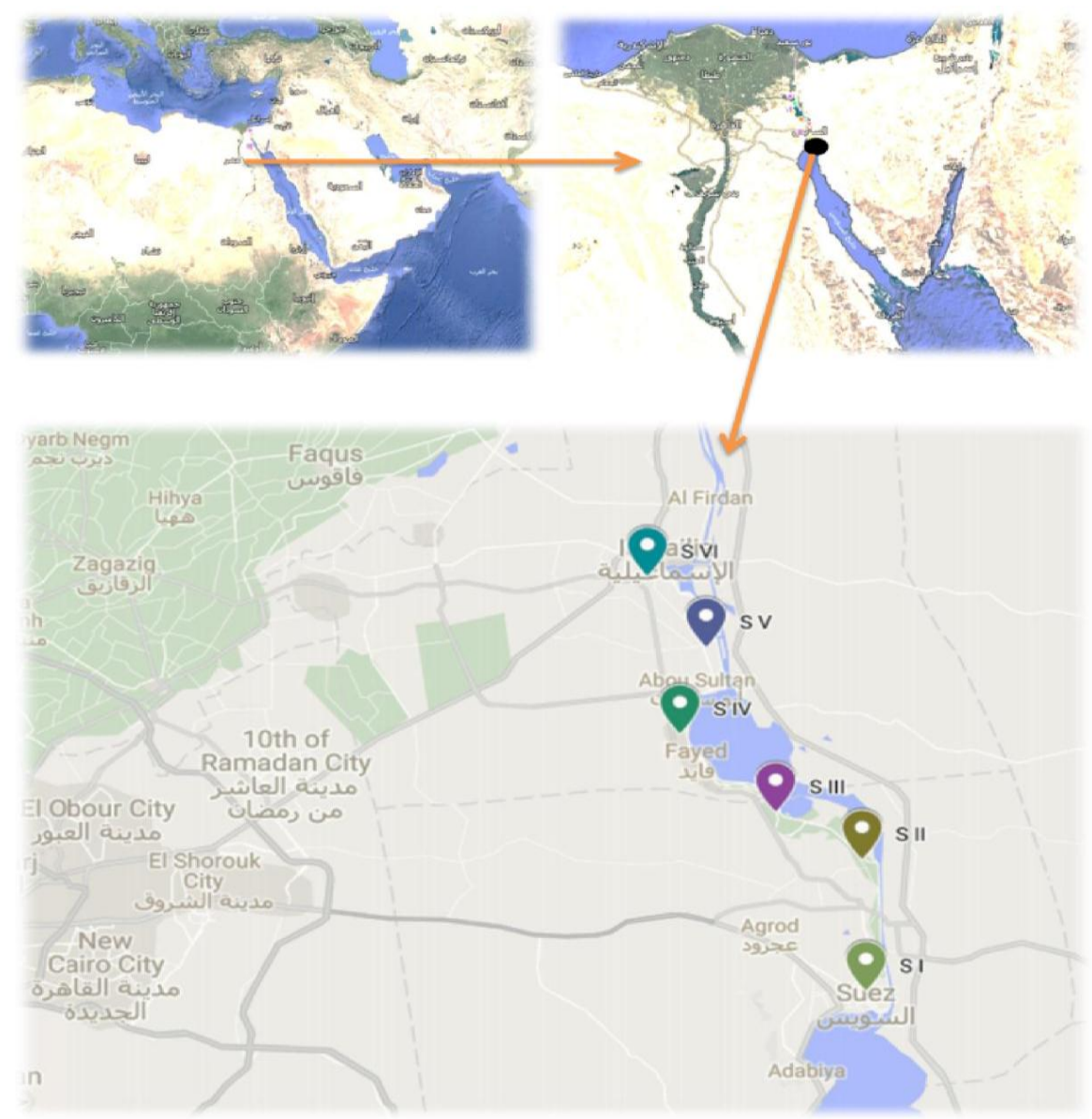

Fig. 1: A map showing the study area of Suez Freshwater Canal 
The water samples for physico-chemical analysis were collected in polyethylene bottles of 1 liter volume, for chlorophyll-a and phytoplankton analysis were collected in 1 liter dark glass bottles, and for bacteriological analysis were collected in $250 \mathrm{ml}$ sterile brown glass bottles. The treated samples were dechlorinated by adding $0.2 \mathrm{ml}$ of $10 \%$ sodium thiosulphate solution to neutralize the residual chlorine (Apha, 2012). The collected samples were transported in ice box to the laboratory of Suez water treatment plant, where the biological, bacteriological and chemical investigations were determined immediately.

\section{Field analysis}

Portable field meters were used to record the subsurface water temperature (glass mercuric thermometer $100^{\circ} \mathrm{C}$ ), $\mathrm{pH}$ (Portable $\mathrm{pH}$ meter, $\mathrm{HACH} \mathrm{CO}$, model HQ40D), total dissolved salts (Portable TDS meter, HACH CO, model HQ430D) and turbidity (Portable Turbidimeter, HACH CO, model 2100P) (Apha, 2012).

\section{Physico-chemical analysis}

Titration analysis of water included detection of total hardness; chlorides and total alkalinity were based on the methods recommended by the American Public Health Association (Apha, 2012). Determination of sulfate, ammonia-n, nitrite-n, nitrate-n, phosphorous, iron, manganese, aluminum, copper and zinc were conducted colormetrically using spectrophotometer $(\mathrm{HACH} \mathrm{CO}$, model DR/2500) according to the methods described in HACH DR /2500 Spectrophotometer procedure manual recommended by US Environment Protection Agency (USEPA, 2005).

\section{Phytoplankton analysis}

For qualitative and quantitative detection of phytoplankton, phytoplankton samples were collected and stored in $500 \mathrm{ml}$ brown glass bottles that have lugol's solution. The technique developed by (Utermöhl, 1958), the organisms in a water sample must be concentrated before analysis (Apha, 2012 and Wetzel and Likens, 1991). Certainly, there are three concentration methods approved by Standard Methods: sedimentation, membrane filtration, and centrifugation (Apha, 2012). In this study we applied the membrane filtration technique. A $500 \mathrm{ml}$ of water sample is filtered through a cellulose membrane filter of $0.45 \mu \mathrm{m}$ pore size at low vacuum pressure to a point where the filter is still just wet. The algae are then brushed off and re-suspended in $50 \mathrm{~mL}$ of distilled water (Apha, 2012 and Hötzel and Croome, 1999). $1 \mathrm{ml}$ was taken from the subsample and put it on the sedgewick rafter cell and let it 15 minute to settle and then investigate the sample, identify and count it using the inverted microscope (Olympus IX 53), the standing crop was calculated as the number of cells and organisms per liter. The method of filtration permits the use of high magnification for identifying and enumerating picoplankters, flagellates, and nonsettling cyanobacteria (Apha, 2012; Weber, 1973 and Wetzel and Likens, 1991). The identification and taxonomy of phytoplankton were followed Baker (2012) and Prescott (1978).

Chlorophyll-a was measured colormetrically by spectrophotometer (Genway co, model 6705) using the methods described in (Apha, 2012). Chlorophyll a concentration was calculated from the following equations:

$$
\begin{aligned}
& C a=11.85(O D 664)-1.54(O D 647)-0.08(O D 630) \\
& \text { Where: } \\
& \mathrm{C} \mathrm{a}=\text { chlorophyll a concentration by } \mu \mathrm{g} / 1 \\
& \text { OD664, OD647 and OD630 = corrected optical densities }
\end{aligned}
$$

Then the amount of pigment per unit volume was calculated by:

$$
\text { Chlorophyll } a(\mu g / l)=\frac{C \text { a } \times \text { extract volume, }(l)}{\text { Volume of samole, }\left(m^{3}\right)}
$$




\section{Treatment of water}

The treatment process inside the plant include pre-chlorination, coagulation/flocculation with aluminum sulfate (Alum), sedimentation, rapid sand filtration and finally chlorine disinfection (Figure 2).

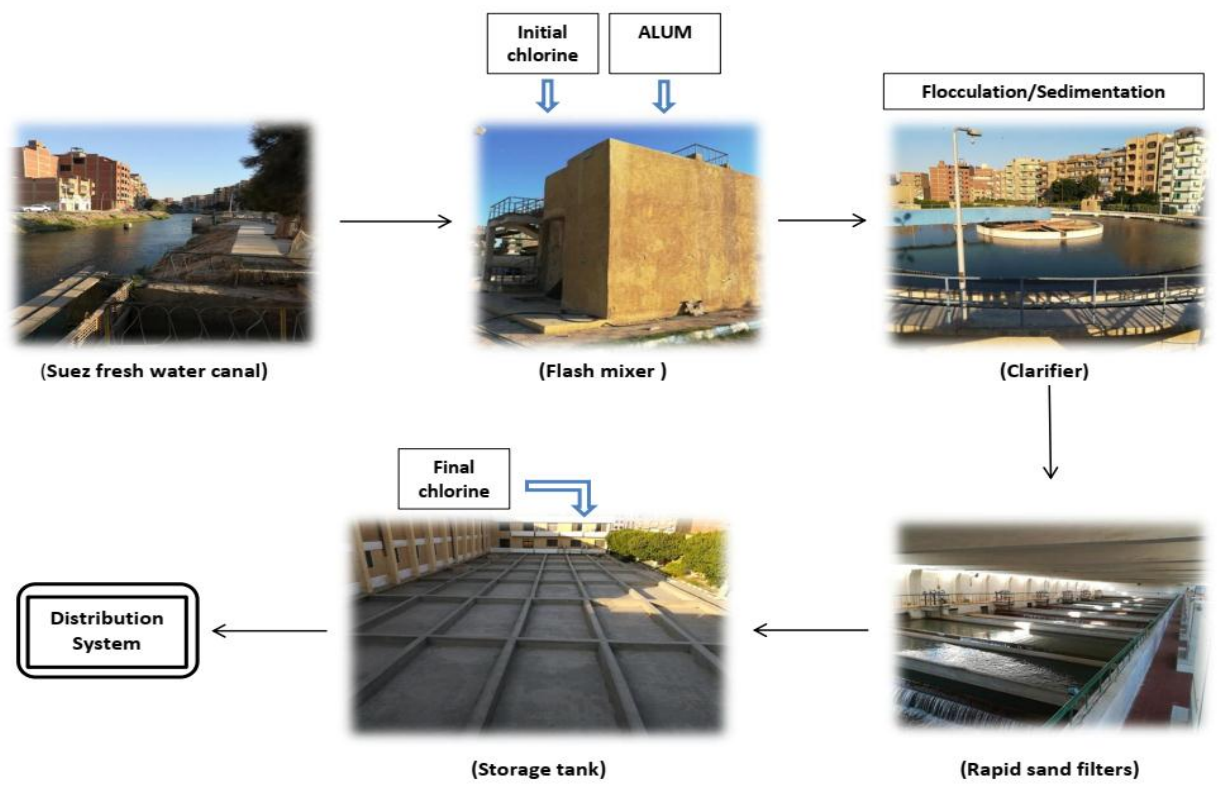

Fig 2: The treatment processes in Suez water treatment plant.

\section{Statistical analysis:}

Correlation analysis

Pearson's correlation analysis was performed to the obtained data to estimate the relation between physico-chemical parameters, phytoplankton density and chlorophyll a using SPSS software version 18.0 for windows.

\section{Principal component analysis (PCA)}

The matrix of physico-chemical parameters, phytoplankton density and chlorophyll a of the investigated samples were subjected to Principal Component Analysis (PCA) (Chessel and Doledec, 1992), this analysis was performed using Sigma Plot software version 10.0.

\section{Cluster analysis:}

Cluster analysis is a simply discovery tool that attempts to arrange the obtained data into groups, when true group memberships are not really regarded. Variations between clustering methods result coming from work with different metrics for similarity or distance between individual vectors, and between groups of vectors (Wilks, 2011), this analysis was performed using Bio diversity professional software version 2.0.

\section{RESULTS AND DISCUSSION}

\section{Physico-chemical results}

Data of physico-chemical parameters of Suez Freshwater Canal are presented in Table 2. The lowest water temperature $\left(14^{\circ} \mathrm{C}\right)$ was recorded in winter while the highest $\left(31^{\circ} \mathrm{C}\right)$ was recorded in summer at most sites. Kebede and Ahlgren (1996) reported that the optimum temperature for phytoplankton growth is $25^{\circ} \mathrm{C}$. 
Table 2: Variation in different ecological parameter at sites I-VI during the four seasons.

\begin{tabular}{|c|c|c|c|c|c|c|c|c|c|c|c|c|c|c|c|c|c|c|c|c|c|c|c|c|c|}
\hline \multirow{3}{*}{ Parameter } & \multirow{3}{*}{ Unit } & \multicolumn{24}{|c|}{ Season } \\
\hline & & \multicolumn{6}{|c|}{ Winter } & \multicolumn{6}{|c|}{ Spring } & \multicolumn{6}{|c|}{ Summer } & \multicolumn{6}{|c|}{ Autumn } \\
\hline & & I & II & III & IV & $\mathbf{V}$ & VI & I & II & III & IV & $\mathbf{V}$ & VI & I & II & III & IV & $\mathbf{V}$ & VI & I & II & & IV & $\mathbf{V}$ & VI \\
\hline Temp & $\left({ }^{\circ} \mathrm{C}\right)$ & 15 & 15 & 15 & 14 & 14 & 14 & 24 & 24 & 23 & 23 & 23 & 22 & 31 & 31 & 30 & 30 & 30 & 29 & 26 & 24 & 24 & 24 & 23 & 23 \\
\hline Turbidity & (NTU) & 7.79 & 6.60 & 5.82 & 5.68 & 5.94 & 5.89 & 14.2 & 22.8 & 15.2 & 13.3 & 14.9 & 8.8 & 14.3 & 27.6 & 15.6 & 16.9 & 11.9 & 13.6 & 18.8 & 12.5 & 18 & 11.8 & 12.9 & 21.8 \\
\hline pH & & 8.03 & 8.16 & 8.18 & 8.23 & 8.24 & 8.24 & 7.84 & 8.06 & 8.09 & 8.14 & 8.21 & 8.33 & 7.91 & 8.01 & 7.98 & 8.21 & 8.24 & 8.30 & 8.35 & 8.23 & 8.13 & 8.03 & 8.07 & 8.04 \\
\hline TDS & $\mathrm{mg} / \mathrm{l}$ & 602 & 480 & 440 & 383 & 380 & 378 & 502 & 387 & 344 & 288 & 286 & 283 & 394 & 311 & 277 & 225 & 226 & 224 & 390 & 418 & 345 & 262 & 257 & 251 \\
\hline Total Hardness & $\mathrm{mg} / \mathrm{l}$ & 200 & 180 & 160 & 152 & 150 & 150 & 172 & 156 & 140 & 120 & 120 & 118 & 144 & 136 & 130 & 110 & 108 & 108 & 170 & 186 & 160 & 140 & 138 & 136 \\
\hline Ca Hardness & $\mathrm{mg} / \mathrm{l}$ & 124 & 110 & 104 & 90 & 88 & 86 & 110 & 90 & 80 & 60 & 70 & 66 & 96 & 84 & 70 & 60 & 58 & 58 & 104 & 112 & 100 & 84 & 82 & 80 \\
\hline Mg Hardness & $\mathrm{mg} / \mathrm{l}$ & 76 & 70 & 56 & 62 & 62 & 64 & 62 & 66 & 60 & 60 & 50 & 52 & 48 & 52 & 60 & 50 & 50 & 50 & 66 & 74 & 60 & 56 & 56 & 56 \\
\hline Cl & $\mathrm{mg} / \mathrm{l}$ & 94 & 66 & 56 & 46 & 44 & 44 & 80 & 52 & 40 & 30 & 20 & 26 & 68 & 42 & 30 & 20 & 18 & 18 & 80 & 86 & 50 & 40 & 40 & 40 \\
\hline $\mathrm{SO}_{4}$ & $\mathrm{mg} / \mathrm{l}$ & 180 & 149 & 131 & 96 & 93 & 93 & 154 & 118 & 93 & 61 & 61 & 54 & 125 & 97 & 74 & 52 & 52 & 52 & 144 & 148 & 136 & 83 & 72 & 70 \\
\hline $\mathrm{NH}_{3}-\mathrm{N}$ & $\mathrm{mg} / \mathrm{l}$ & 0.28 & 0.28 & 0.26 & 0.26 & 0.24 & 0.21 & 0.25 & 0.24 & 0.09 & 0.01 & 0.11 & 0.03 & 0.05 & 0.07 & 0.01 & 0.02 & 0.04 & 0.07 & 0.37 & 0.27 & 0.18 & 0.11 & 0.15 & 0.32 \\
\hline & $\mathrm{mo} / \mathrm{l}$ & 0.013 & 0007 & 0,020 & 0.00 & 0.00 & 0.01 & 0.01 & 0.01 & 0.01 & 0.01 & 0.01 & 0.01 & 0.00 & 0.00 & 0.01 & 0.00 & 0.00 & 0.00 & 0.00 & 0.00 & 0.01 & 0.00 & 0.03 & 0.00 \\
\hline $\mathrm{NO}_{2}-\mathrm{N}$ & $\mathrm{mg} / \mathrm{I}$ & 0.013 & 0.001 & 0.020 & 8 & 8 & 4 & 1 & 0 & 5 & 1 & 2 & 0 & 9 & 9 & 1 & 1 & 1 & 4 & 4 & 2 & 2 & 1 & 1 & 1 \\
\hline $\mathrm{NO}_{3}-\mathrm{N}$ & $\mathrm{mg} / \mathrm{l}$ & 0.6 & 0.6 & 0.5 & 0.5 & 0.4 & 0.3 & 0.3 & 0.1 & 0.5 & 0.3 & 0.3 & 0.2 & 0.1 & 0.1 & 0.2 & 0.1 & 0.1 & 0.2 & 0.1 & 0.1 & 0.3 & 0.1 & 0.2 & 0.6 \\
\hline $\mathrm{PO}_{4}-\mathrm{P}$ & $\mathrm{mg} / \mathrm{l}$ & 0.45 & 0.38 & 0.30 & 0.15 & 0.17 & 0.20 & 0.45 & 0.32 & 0.19 & 0.31 & 0.72 & 0.16 & 0.10 & 0.22 & 0.24 & 0.16 & 0.09 & 0.10 & 0.57 & 0.96 & 0.78 & 0.78 & 1.03 & 1.67 \\
\hline $\mathbf{F e}$ & $\mathrm{mg} / \mathrm{l}$ & 0.06 & 0.03 & 0.005 & 0.06 & 0.00 & 0.08 & 0.18 & 0.46 & 0.18 & 0.10 & 0.08 & 0.13 & 0.11 & 0.22 & 0.09 & 0.06 & 0.05 & 0.08 & 0.11 & 0.06 & 0.03 & 0.02 & 0.01 & 0.02 \\
\hline $\mathrm{Mn}$ & $\mathrm{mg} / \mathrm{l}$ & 0.076 & 0.073 & 0.072 & 0.07 & 0.04 & 0.07 & 0.09 & 0.08 & 0.08 & 0.07 & 0.05 & 0.08 & 0.08 & 0.07 & 0.07 & 0.07 & 0.05 & 0.07 & 0.10 & 0.10 & 0.11 & 0.08 & 0.10 & 0.14 \\
\hline 1 & $m g / 1$ & 0.070 & 0.075 & 0.072 & 0 & 2 & 5 & 1 & 6 & 4 & 6 & 6 & 8 & 1 & 9 & 7 & 4 & 1 & 8 & 6 & 4 & 8 & 9 & 2 & 8 \\
\hline Al & $\mathrm{mo} / \mathrm{l}$ & 0.081 & 0.077 & 0102 & 0.09 & 0.12 & 0.07 & 0.07 & 0.03 & 0.03 & 0.04 & 0.00 & 0.04 & 0.07 & 0.10 & 0.09 & 0.08 & 0.15 & 0.09 & 0.07 & 0.24 & 0.29 & 0.28 & 0.28 & 0.23 \\
\hline AI & $\mathrm{mg} / \mathrm{l}$ & 0.081 & 0.072 & 0.102 & 3 & 6 & 2 & 2 & 0 & 3 & 3 & 1 & 2 & 4 & 6 & 9 & 8 & 3 & 5 & 2 & 7 & 1 & 9 & 2 & 1 \\
\hline
\end{tabular}


The clarity of a natural body of water is a major determinant of its condition and productivity (Apha, 1998). It is clearly observed from the data shown in Table 2 that the lowest turbidity recorded in winter (5.68-7.79 ntu). Siliem (1995) reported that the turbidity degree of stream water is an approximate measure of the intensity of the pollution. Hydrogen ion concentration $(\mathrm{pH})$ is an important environmental factor that control of all aquatic chemical and biological processes, controls the solubility of metal ions, and affects natural aquatic life. $\mathrm{pH}$ values in the present study were in the alkaline side (7.84-8.35), small local differences were observed with no clear seasonal variations. These results were in agreement with El-Hady and Hussian (2012) who reported that the Ismailia Canal was always on the alkaline side ( $\mathrm{pH}>7)$.

It is clear from data presented in Table 2 and Figure 3 that the total dissolved salts (TDS) of water were found to be higher in site I in all seasons in winter, spring, summer and autumn (602, 502, 394 and $390 \mathrm{mg} / \mathrm{l}$ respectively) than in site VI (378, 283, 224 and $251 \mathrm{mg} / \mathrm{l}$ respectively). The higher values at site I during the four seasons are related to the end side of the canal. The high concentrations of TDS were showed in winter and the minimum in summer and autumn seasons, that may be due to the rainfall which may cause gradual disturbances in sedimentation of solids. These results were in agreement with El-hady (2014) who reported that the highest TDS value was reached in winter $568 \mathrm{mg} / \mathrm{l}$ in River Nile. The elevated levels of turbidity refer to course particles and phytoplankton in the water. Pollution contributes to the high level of turbidity that affects water clarity. It is composed of the organic and inorganic materials like sediment, algae, and pollutants. Water pollution due to the dumping of sewage into the sea is a main manmade hazard of the environment today. The data suggest that there is an increase volume of garbage disposed along with the increased population. Constant assessment and policy implementation related to sewage disposal to the water canals must be strictly imposed mostly in the sources of drinking water.

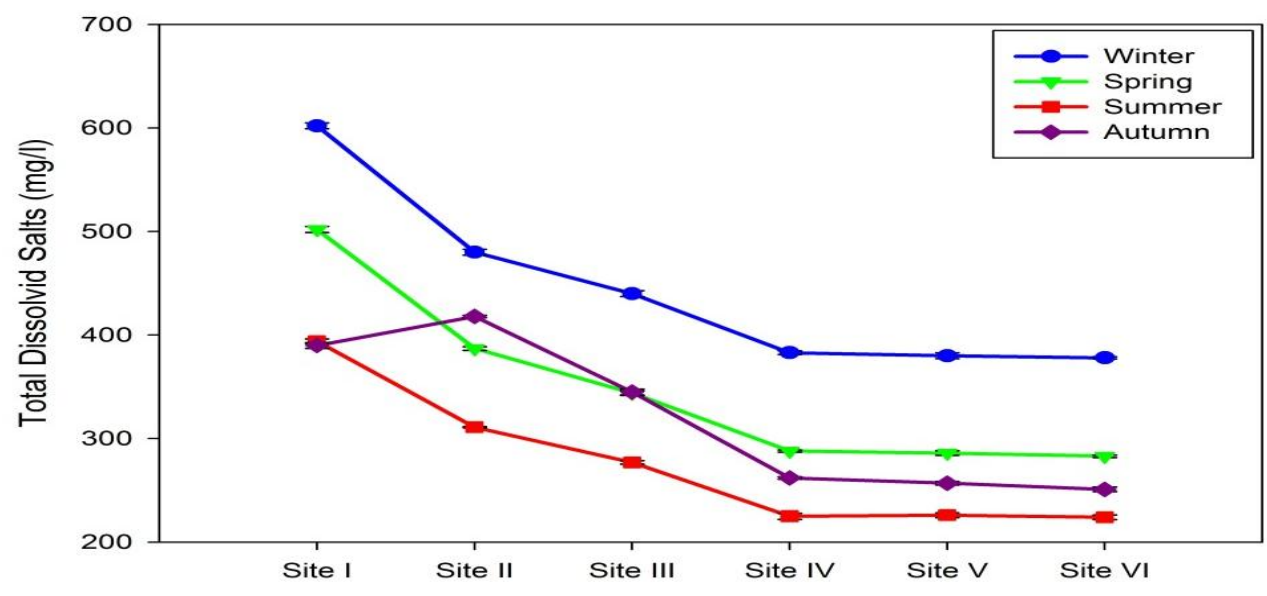

Fig 3: Seasonally variations in TDS at different sites I-VI.

Data in Table 2 showed that the total hardness varied between 108 at site VI and $200 \mathrm{mg} / \mathrm{l}$ at site I, its lowest values recorded in summer (108-144) $\mathrm{mg} / \mathrm{l}$ and the highest in winter (150-200) mg/l. Calcium hardness varied between 58 at site VI and $124 \mathrm{mg} / \mathrm{l}$ at site I, its lowest values recorded in summer (58-96) $\mathrm{mg} / \mathrm{l}$ and the highest in winter (86-124) mg/l. Chlorides varied between 18 at site VI and $94 \mathrm{mg} / \mathrm{l}$ at site I, its lowest values recorded in summer (18-68) $\mathrm{mg} / \mathrm{l}$ and the highest in winter (44-94) $\mathrm{mg} / \mathrm{l}$. Sulfate varied between 52 at site VI and $180 \mathrm{mg} / \mathrm{l}$ at site I, its lowest values recorded in summer (52-125) $\mathrm{mg} / \mathrm{l}$ and the highest in winter (93-180) $\mathrm{mg} / \mathrm{l}$. Shaaban- 
Dessouki et al. (2004) showed that the conductivity and sulfate were found to be higher within the discharged water than that of the up-stream water in River Nile.

The lowest phosphorus values (Table 2) recorded in summer $(0.1-0.24) \mathrm{mg} / \mathrm{l}$ and the highest in autumn $(0.57-1.67) \mathrm{mg} / \mathrm{l}$. Phosphate values were under the maximum limit in all sites except site VI (Abu Atwa) at Ismailia city where the phosphate concentration exceed the Egyptian standard limits (EWQS, 2007) reached to $1.67 \mathrm{mg} / \mathrm{l}$. The lowest ammonia concentrations were recorded in summer $(0.01-$ $0.07) \mathrm{mg} / \mathrm{l}$ and the highest concentrations of nitrate were recorded in winter $(0.3-0.6)$ $\mathrm{mg} / \mathrm{l}$.

Data in Table 2 show that the minimum values of iron were recorded in winter (0.00-0.08) $\mathrm{mg} / \mathrm{l}$ while the maximum in spring (0.08-0.46) $\mathrm{mg} / \mathrm{l}$. Manganese minimum concentrations appeared in winter $(0.042-0.076) \mathrm{mg} / \mathrm{l}$ while the maximum were recorded in autumn (0.089-0.148) $\mathrm{mg} / \mathrm{l}$. The results showed that the highest concentrations of aluminum appeared in autumn season $(0.072-0.291) \mathrm{mg} / \mathrm{l}$ and the lowest concentrations in spring (0.001-0.030) mg/l. Aluminum concentrations at site I were stable throughout the four seasons which ranged between $(0.072-0.081) \mathrm{mg} / \mathrm{l}$, these results may be because site I is located at the end side of the canal. The highest concentrations of phosphorus which is the key element of eutrophication appeared at site VI (1.67) mg/l.

\section{Biological results}

The phytoplankton structure (Table 3 ) revealed a highest genera and species number $(38,52)$ respectively at site II and site I in spring, decreased to $(15,19)$ respectively at site $I$ in autumn. Chlorophyll a measured values showed greatly associated with variations in cell counts, which greatly reduced in drinking water plant in accordance with the reduction of species and their counts. Figure 4 showed that chlorophyll a varied between 3.39 at site I and $29.3 \mathrm{mg} / \mathrm{l}$ at site VI. Its exhibited lowest values during autumn (3.39-22.9) $\mathrm{mg} / \mathrm{l}$, while the highest values during summer (12.9-29.3) $\mathrm{mg} / \mathrm{l}$. its concentration are reflecting the number of individuals.

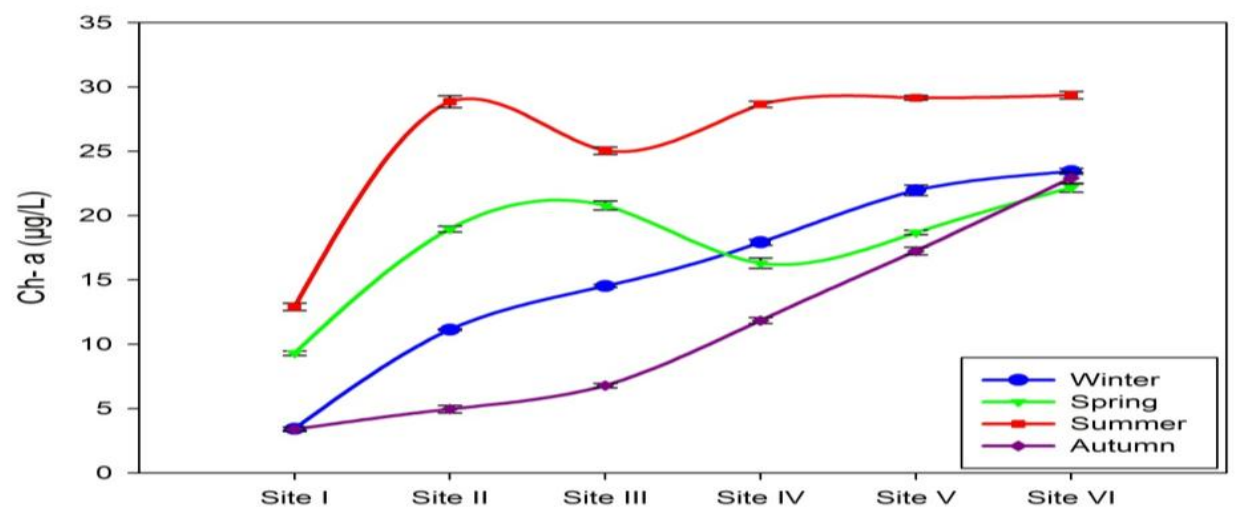

Fig 4: Seasonally variations in Chlorophyll-a at different sites I-VI.

These results were in agreement with El-Hady and Hussian (2012) who reported that the peak algal biomass in River Nile was in autumn, while the highest cell density occurred in spring. Chlorophyll a showed positive correlations with phytoplankton cell density with correlations of 0.746 , these results were in agreement with Shaaba et al. (2011) who reported that there was a positive relation observed between the fluctuations of total chlorophyll contents of the phytoplankton and those of total number of individuals at all investigated sites of Rosetta branch in River Nile. Figure 5 showed that the total algal count varied between 2500 at site I and 31236.67 
cell/l at site VI. The highest count recorded in spring (16863.3-31236.6) cell/1 and the lowest in autumn (2500-11370) cell/l. these results were in agreement with ElManawy and Amin (2004) who observed that the total crop increased rapidly at the beginning of November 2003 and the highest cell counts were encountered in February 2004 in Suez Freshwater Canal. The lower count at site I throughout the four seasons is related to the end of the canal.

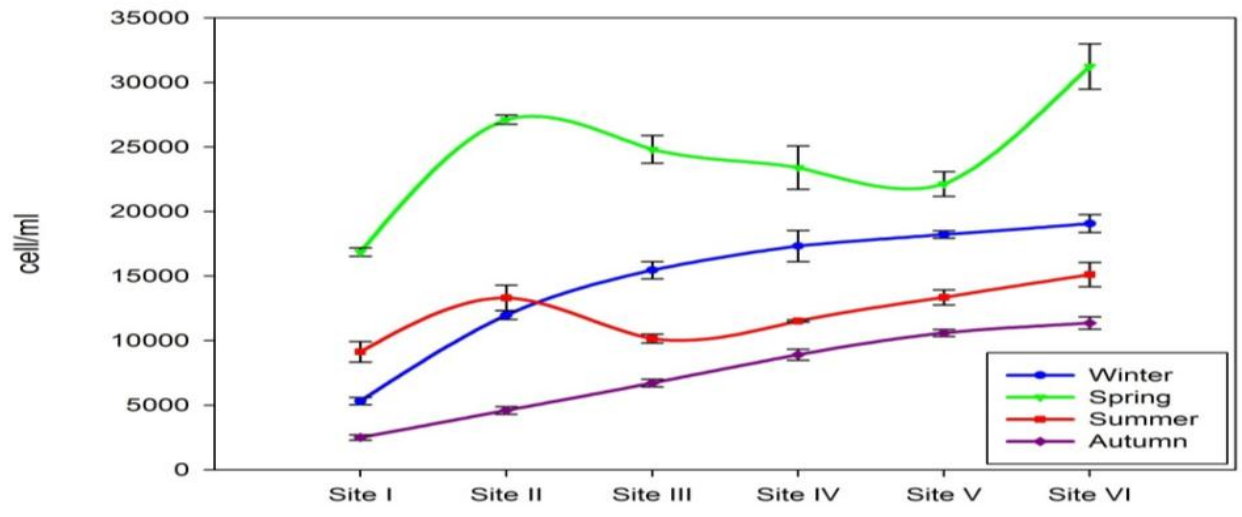

Fig 5: Seasonally variations in Phytoplankton cell count at different sites I-VI.

From the annual study of the algal composition, 106 total algal taxa belonging to 54 different genera were identified. Chlorophyta (27 genera, 51 species), Bacillariophyta (11 genera, 30 species), Cyanophyta (10 genera, 16 species), Euglenophyta (3 genera, 4 species), Cryptophyta (1 genus, 3 species), Crysophyta (1 genus, 1 species) and Dinophyta (1 genus, 1 species). The minimum phytoplankton growth was in the end side of the canal at site I. Cyanophyta was dominant by species of Merismopedia followed by Microcystis, Oscillatoria and Aphanocapsa. Chlorophyta was dominant by Scenedesmus followed by Pediastrum, Coelastrum and Actinastrum. Bacillariophyta was dominant by Fragillaria followed by Cyclotella, Melosira, Synedra and Nitzchia. Abdel-Karim (1999) showed that the most prevailing Bacillariophyceae were Cyclotella meneghiniana, Cyclotella ocellata, Melosira granulate and Synedra ulna in Damietta branch. Amin (2007) stated that Scenedesmus quadricuda and Actinastrum hantzschii were the most dominant species in Ismailia canal. Cyanophyta was the most elaborated group at site (II, III, IV, V, VI). It formed about $(46.35,45.62,50.77,46.01$ and $51.57 \%$ respectively) from the total phytoplankton standing crop (cell number), while it formed the second elaborated group at site I with percent $35.13 \%$. These results were in agreement with Shaaban-Dessouki et al. (2004) who reported that Cyanophyta was the most elaborated group of phytoplankton in River Nile. Bacillariophyta formed the second elaborated group at site (IV, V, VI). It formed about $(25.13,30.43$, and 29.62\% respectively) from the total phytoplankton standing crop (cell number), while it formed the third position group at site (I, II, III) with percent $(14.09,19.01$, and $19.29 \%$ respectively). Chlorophyta formed the first position group at site I with percent $49.96 \%$, second at site (II, III) with percent $(34.28,34.66 \%)$ and third at site (IV, V, VI) with percent $(23.61,23.16$ and $18.61 \%$ respectively). Figure (6 a, b, c and d) shows the algal phylum distribution at sites (I- VI) in winter, spring, summer and autumn respectively. In this work we found that the highest appearance of Bacillariophytes was at cold temperatures (Figure $7 \mathrm{c}$ ), while Chlorophytes and Cyanophytes were at warm temperatures (Figure $7 \mathrm{a}, \mathrm{b}$ ). Grover et al. (1999) found that, seasonal succession of phytoplankton consisted of a shift from relatively large 
celled diatoms, chlorophytes and flagellates at cold temperature to small celled colonial and filamentous cyanophytes at worm temperature in Cedar Creek Lake and Eagle Mountain Lake.
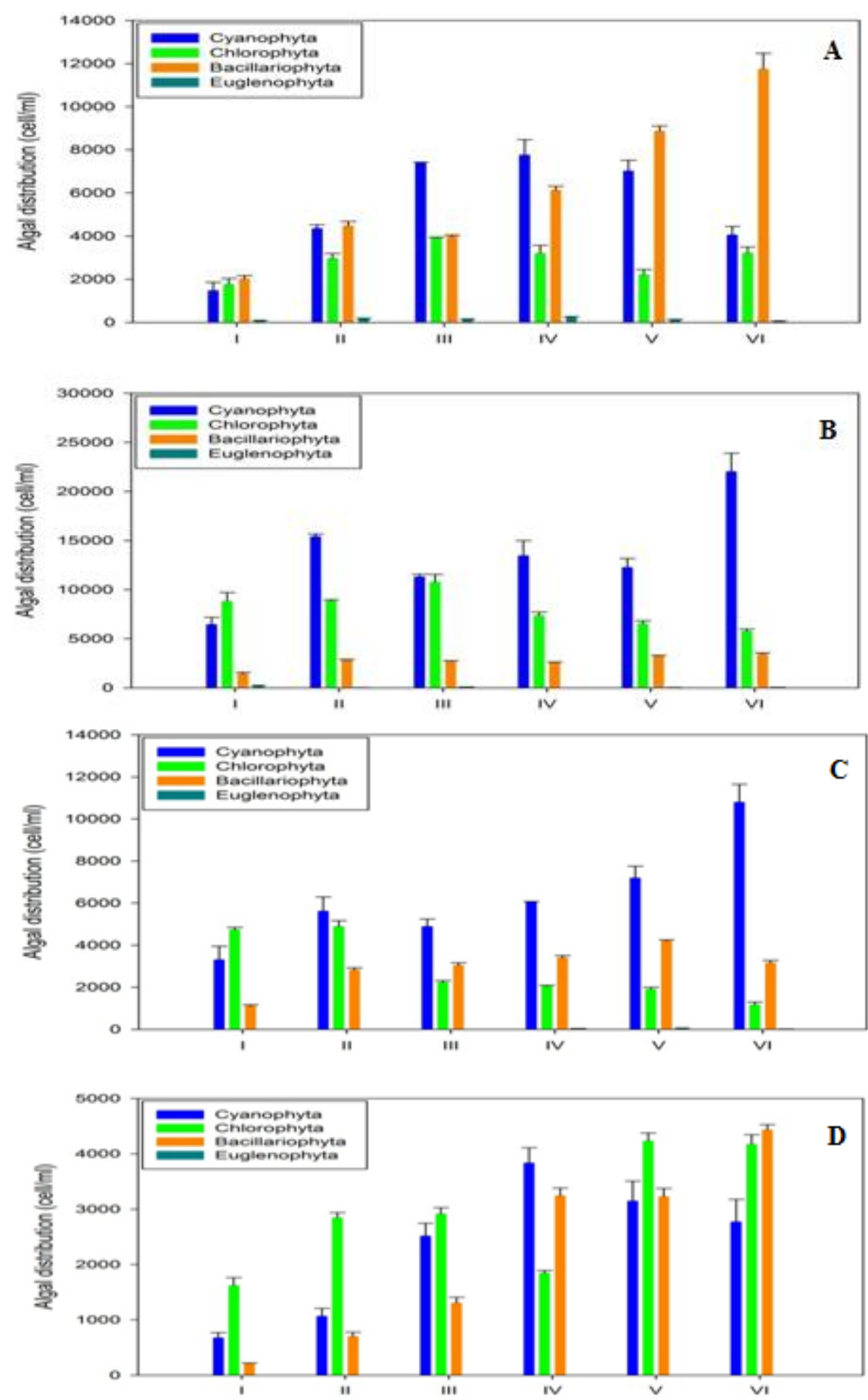

Fig. 6: Algal phylum distribution at sites (I- VI) in (a) winter, (b) spring, (c) summer and (d) autumn.

Sobhy (1999) mentioned that the Chlorophyceae percent was maximum in spring and minimum in winter in River Nile. Chlorophyta recorded the highest count in spring ranged from 1690 to 2346.67 cell/l (Figure 7 a). Cyanophyta varied between 673.3 at site I and 22003.3 cell/1 at site VI. The highest count recorded in spring 
(6440-22003.3) cell/1 and the lowest in autumn (673.3-3833.3) cell/l (Figure $7 \mathrm{~b}$ ). Bacillariophyta varied between 210 at site I and 11736.67 cell/l at site VI. The highest count recorded in winter (2016.67-11736.67) cell/l and the lowest in autumn (210-4430) cell/l (Figure 7 c). Euglenophyta recorded the highest count in winter ranged from (66.6 to 230) cell/l.
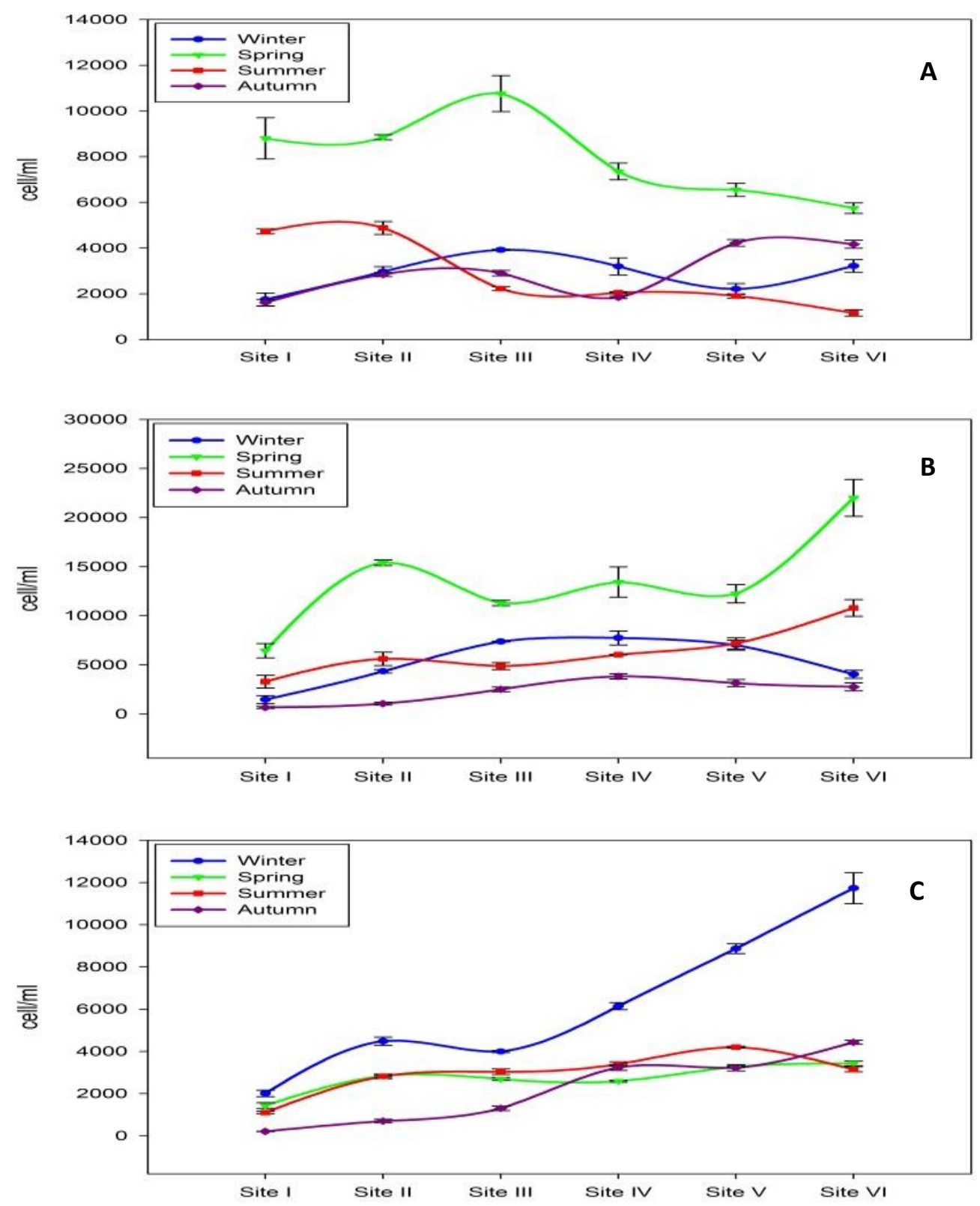

Fig. 7: Seasonally variations in (a) Chlorophyta, (b) Cyanophyta and (c) Bacillariophyta at different sites I-VI.

Chlorophyll a showed positive correlations with temperature with correlations coefficients of 0.581 and negative correlations with chlorides concentration ( $\mathrm{r}=$ 0.663). Chlorophyta showed negative correlations with chlorides concentrations with correlations coefficients of -0.601 . Bacillariophyta showed positive correlations with total hardness with correlations coefficients of 0.582 , Magnesium hardness ( $\mathrm{r}=$ $0.605)$, Nitrate concentration $(r=0.621)$ and copper $(r=0.755)$. 


\begin{tabular}{|c|c|c|c|c|c|c|c|c|c|c|c|c|c|c|c|c|c|}
\hline \multirow[t]{2}{*}{ Season } & \multirow[t]{2}{*}{ Site } & \multicolumn{2}{|c|}{ Cyanophyta } & \multicolumn{2}{|c|}{ Chlorophyta } & \multicolumn{2}{|c|}{ Bacillariophyta } & \multicolumn{2}{|c|}{ Euglenophyta } & \multicolumn{2}{|c|}{ Dinophyta } & \multicolumn{2}{|c|}{ Chrysophyta } & \multicolumn{2}{|c|}{ Cryptophyta } & \multirow{2}{*}{$\begin{array}{c}\text { Total } \\
\text { genera }\end{array}$} & \multirow{2}{*}{$\begin{array}{c}\text { Total } \\
\text { species }\end{array}$} \\
\hline & & genera & species & genera & species & genera & species & genera & species & genera & species & genera & species & genera & species & & \\
\hline \multirow{6}{*}{ 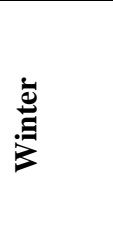 } & $\mathbf{I}$ & 4 & 5 & 12 & 20 & 8 & 13 & 2 & 2 & 1 & 1 & 0 & 0 & 0 & 0 & 27 & 41 \\
\hline & II & 7 & 8 & 14 & 20 & 8 & 17 & 2 & 2 & 1 & 1 & 0 & 0 & 0 & 0 & 32 & 48 \\
\hline & III & 5 & 7 & 12 & 20 & 6 & 16 & 2 & 2 & 0 & 0 & 0 & 0 & 0 & 0 & 25 & 45 \\
\hline & IV & 5 & 6 & 15 & 21 & 8 & 17 & 2 & 2 & 0 & 0 & 0 & 0 & 0 & 0 & 30 & 46 \\
\hline & $\mathbf{V}$ & 6 & 8 & 13 & 16 & 8 & 17 & 1 & 1 & 0 & 0 & 0 & 0 & 0 & 0 & 28 & 42 \\
\hline & VI & 7 & 8 & 11 & 15 & 7 & 17 & 1 & 1 & 0 & 0 & 0 & 0 & 0 & 0 & 26 & 41 \\
\hline \multirow{6}{*}{ ڤ) } & I & 7 & 8 & 15 & 25 & 9 & 17 & 2 & 2 & 0 & 0 & 0 & 0 & 0 & 0 & 33 & 52 \\
\hline & II & 6 & 8 & 21 & 30 & 9 & 18 & 1 & 1 & 1 & 1 & 0 & 0 & 0 & 0 & 38 & 48 \\
\hline & III & 5 & 5 & 14 & 21 & 7 & 14 & 2 & 2 & 1 & 1 & 0 & 0 & 0 & 0 & 29 & 43 \\
\hline & IV & 5 & 6 & 16 & 23 & 7 & 13 & 1 & 1 & 1 & 1 & 0 & 0 & 0 & 0 & 30 & 44 \\
\hline & $\mathbf{V}$ & 7 & 7 & 17 & 23 & 8 & 16 & 2 & 2 & 1 & 1 & 0 & 0 & 1 & 1 & 36 & 50 \\
\hline & VI & 6 & 8 & 19 & 24 & 7 & 16 & 2 & 2 & 1 & 1 & 0 & 0 & 0 & 0 & 35 & 51 \\
\hline \multirow{6}{*}{$\bar{B}$} & I & 5 & 6 & 12 & 16 & 8 & 14 & 0 & 0 & 0 & 0 & 0 & 0 & 0 & 0 & 25 & 36 \\
\hline & II & 4 & 4 & 11 & 16 & 8 & 16 & 0 & 0 & 0 & 0 & 0 & 0 & 0 & 0 & 23 & 36 \\
\hline & III & 4 & 4 & 12 & 14 & 7 & 12 & 0 & 0 & 1 & 1 & 0 & 0 & 0 & 0 & 24 & 31 \\
\hline & IV & 2 & 2 & 8 & 11 & 7 & 13 & 1 & 1 & 0 & 0 & 0 & 0 & 0 & 0 & 18 & 27 \\
\hline & $\mathbf{V}$ & 2 & 3 & 9 & 13 & 8 & 13 & 1 & 1 & 0 & 0 & 0 & 0 & 0 & 0 & 20 & 30 \\
\hline & VI & 3 & 4 & 9 & 12 & 7 & 13 & 1 & 1 & 0 & 0 & 0 & 0 & 0 & 0 & 20 & 30 \\
\hline \multirow{5}{*}{ छี } & I & 2 & 2 & 8 & 10 & 5 & 7 & 0 & 0 & 0 & 0 & 0 & 0 & 0 & 0 & 15 & 19 \\
\hline & II & 5 & 5 & 14 & 18 & 8 & 10 & 0 & 0 & 0 & 0 & 0 & 0 & 0 & 0 & 27 & 33 \\
\hline & III & 4 & 4 & 18 & 24 & 7 & 12 & 0 & 0 & 0 & 0 & 0 & 0 & 0 & 0 & 29 & 40 \\
\hline & IV & 4 & 5 & 11 & 17 & 7 & 11 & 0 & 0 & 0 & 0 & 0 & 0 & 0 & 0 & 22 & 33 \\
\hline & $\mathbf{V}$ & 5 & 5 & 18 & 21 & 7 & 11 & 0 & 0 & 0 & 0 & 0 & 0 & 0 & 0 & 30 & 37 \\
\hline
\end{tabular}




\section{Principal Component Analysis (PCA)}

Component axes 1 and 2 explained $58.5 \%$ of the variance (Figure 8 ) with the first explaining the bulk of it (39.1\%). Total phytoplankton, Cyanophyta, Chlorophyta and chlorophyll a are positively correlated to temperature and can undergo a low amount of ammonia, phosphate, manganese, alkalinity and chlorides whereas Euglenophyta, Crysophyta are negatively correlated. Bacillariophyta were highly positively associated with nitrate, nitrite and copper and negatively with zinc, aluminum, iron, turbidity and $\mathrm{pH}$. Chrysophyta were positively correlated with zinc, aluminum, iron, turbidity and $\mathrm{pH}$ and negatively with nitrate, nitrite and copper.

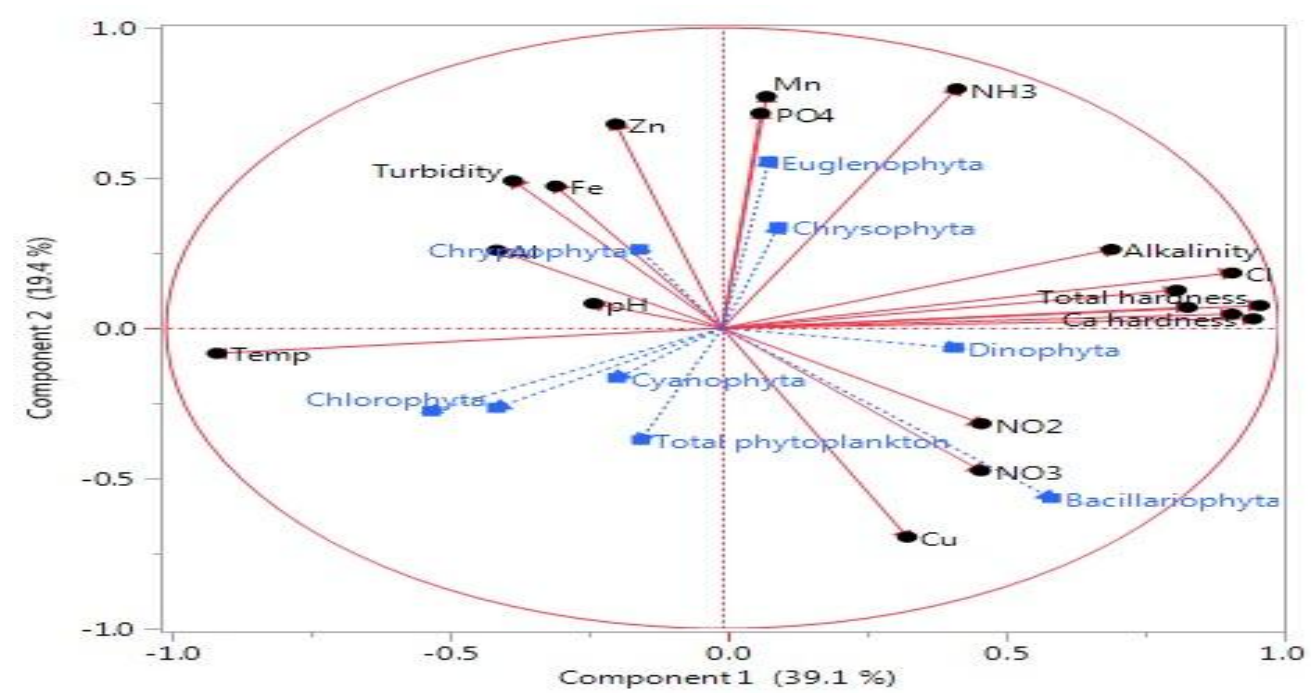

Fig. 8: Principal component analysis (PCA) between environmental and biological variables in Suez Freshwater Canal at site I.

\section{Cluster analysis}

According to the cluster analysis (Figure 9), maximum similarity percent of 95.33\% was recorded between site IV and V. site III, IV and V were clustered at similarity level $94.06 \%$. While the lowest similarity of $74.37 \%$ was recorded at site I and site (II, III, IV, V, and VI).

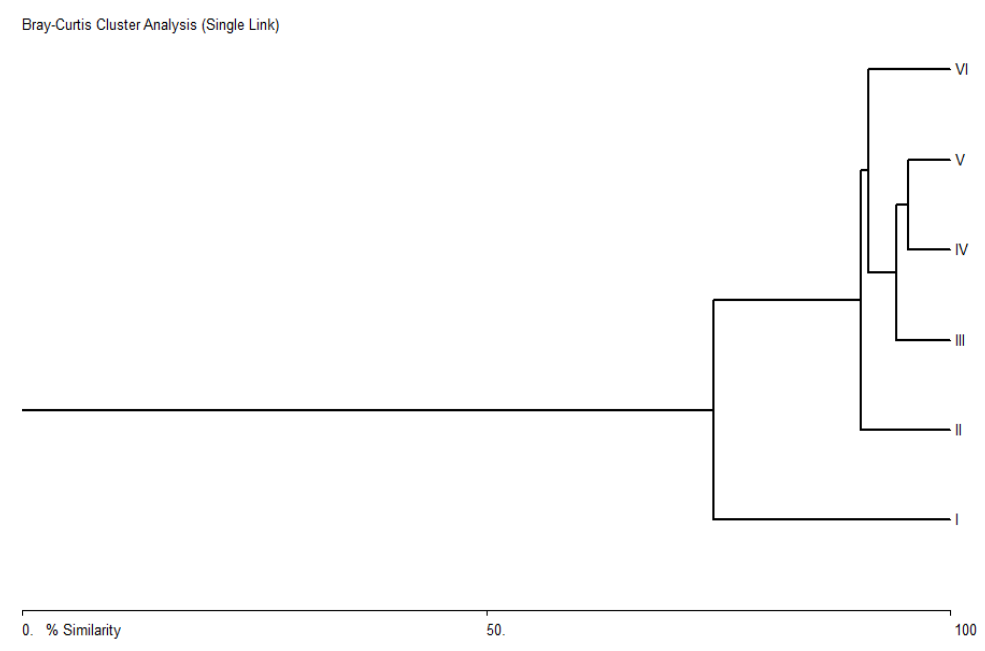

Fig. 9: Cluster analysis of phytoplankton cell density at different sites I-VI. 


\section{Water treatment results}

Data in Table 4 showed the physico-chemicals and microbiological analysis results of the treated drinking water from the Suez water treatment plant. All results approved by the Egyptian drinking water quality standards (EWQS, 2007). But turbidity results $(0.71,0.6 \mathrm{ntu})$ in summer and autumn respectively, and TDS in winter $(613 \mathrm{mg} / \mathrm{l})$ exceeded the maximum permissible limits for drinking of World health organization (WHO, 2011).

Table 4: Analysis of the treated drinking water from the Suez Water Treatment Plant during the four seasons.

\begin{tabular}{|c|c|c|c|c|c|c|c|}
\hline Parameters & Unit & Winter & Spring & Summer & Autumn & $\begin{array}{c}\text { Egyptian } \\
\text { standards } \\
2007\end{array}$ & $\begin{array}{c}\text { WHO } \\
2011\end{array}$ \\
\hline Temp & $\left({ }^{\circ} \mathrm{C}\right)$ & 15 & 23 & 30 & 25 & ------ & ------ \\
\hline Turbidity & (NTU) & 0.5 & 0.5 & 0.71 & 0.6 & 1 & 0.5 \\
\hline $\mathrm{pH}$ & & 7.3 & 7.1 & 7.5 & 7.8 & $6.5-8.5$ & $6.5-8.5$ \\
\hline TDS & $\mathrm{mg} / \mathrm{l}$ & 613 & 515 & 408 & 462 & 1000 & 600 \\
\hline T. Hardness & $\mathrm{mg} / \mathrm{l}$ & 202 & 172 & 158 & 180 & 500 & 500 \\
\hline Ca Hardness & $\mathrm{mg} / \mathrm{l}$ & 122 & 110 & 100 & 120 & 350 & 300 \\
\hline Mg Hardness & $\mathrm{mg} / \mathrm{l}$ & 80 & 62 & 58 & 60 & 150 & ------ \\
\hline $\mathrm{Cl}$ & $\mathrm{mg} / \mathrm{l}$ & 104 & 92 & 82 & 82 & 250 & 250 \\
\hline Alkalinity & $\mathrm{mg} / \mathrm{l}$ & 134 & 140 & 110 & 130 & 500 & 300 \\
\hline $\mathrm{SO} 4$ & $\mathrm{mg} / \mathrm{l}$ & 192 & 172 & 138 & 159 & 250 & 250 \\
\hline NH3-N & $\mathrm{mg} / \mathrm{l}$ & 0.001 & 0.04 & 0.001 & 0.01 & 0.5 & 1.5 \\
\hline $\mathrm{NO} 2-\mathrm{N}$ & $\mathrm{mg} / \mathrm{l}$ & 0.004 & 0.005 & 0.001 & 0.001 & 0.2 & 3.0 \\
\hline NO3-N & $\mathrm{mg} / \mathrm{l}$ & 1.4 & 1 & 1.1 & 0.6 & 45 & 50 \\
\hline PO4-P & $\mathrm{mg} / \mathrm{l}$ & 0.15 & 0.1 & 0.05 & 0.05 & ------ & ------ \\
\hline $\mathrm{Fe}$ & $\mathrm{mg} / \mathrm{l}$ & 0.01 & 0.05 & 0.05 & 0.03 & 0.3 & 0.3 \\
\hline Mn & $\mathrm{mg} / \mathrm{l}$ & 0.01 & 0.031 & 0.02 & 0.031 & 0.4 & 0.1 \\
\hline $\mathrm{Cu}$ & $\mathrm{mg} / \mathrm{l}$ & 0.06 & 0.01 & 0.04 & 0.01 & 2 & 2.0 \\
\hline $\mathrm{Zn}$ & $\mathrm{mg} / \mathrm{l}$ & 0.02 & 0.03 & 0.01 & 0.01 & 3 & 0.1 \\
\hline $\mathrm{Al}$ & $\mathrm{mg} / \mathrm{l}$ & 0.12 & 0.12 & 0.122 & 0.15 & 0.2 & 0.2 \\
\hline $\begin{array}{l}\text { Total } \\
\text { Bacteria } \\
\text { Count }\end{array}$ & $\mathrm{CFU} / \mathrm{ml}$ & 3.67 & 2.67 & 2 & 0.333 & $\leq 50$ & ------ \\
\hline $\begin{array}{l}\text { Total } \\
\text { Coliform }\end{array}$ & $\mathrm{CFU} / \mathrm{ml}$ & 0 & 0 & 0 & 0 & $<1$ & $<1$ \\
\hline Ch. a & $\mu \mathrm{g} / 1$ & 0.188 & 0.1754 & 0.1594 & 0 & ------ & ------ \\
\hline $\begin{array}{l}\text { Total Algal } \\
\text { Count }\end{array}$ & $\mathrm{Cell} / \mathrm{ml}$ & 140 & 66.67 & 53.333 & 0 & ------ & ------ \\
\hline
\end{tabular}

\section{CONCLUSION}

Suez Freshwater Canal is the main source of freshwater supply to Suez governorate which extending from the Ismailia Canal. Ismailia Canal extending eastward for about $125 \mathrm{~km}$ from the River Nile at Shupra, to Ismailia city at which it bifurcates into two arms, one to the south to Suez governorate and the other to the north to Portsaid governorate. Due to the great importance of Suez Freshwater Canal as the major drinking water source for about 500000 capita, and because of large amounts of wastes, untreated wastewater and rural domestic wastes discharge into this canal. The current findings indicate the quality of the used water treatment method and the applicability of the treated water as drinking water according to the Egyptian drinking water quality standards and World Health Organization. Also, the 
results revealed a change in the physical, chemical, and biological properties in the Suez Freshwater Canal over the months of the year. The results showed that the change in temperature with the change of seasons has a big role in that change. As the highest density of phytoplankton was is in the spring and the lowest in the autumn. The density of algae in Site VI (Abu Atwa) is more than that in Site I (El Hawes, Intake of Suez water treatment plant) throughout the seasons of the year.

\section{CONFLICT OF INTEREST}

The authors declare that there is no any conflict of interest.

\section{REFERENCES}

Abdel-Aal, E.I. (2006). The use of benthic algae as water quality indicators. M. Sc. thesis, Botany department, Faculty of Science, Mansoura University, Mansoura, Egypt.

Abdel-Karim, M.S. (1999). Phytoplankton Dynamic and its productivity in Damietta Branch. M. Sc. Thesis, Girls College, Ain Shams University, Egypt.

Abdo, M.H. (1998). Some environmental studies on the River Nile and Ismailia Canal in front of the industrial area of Shoubra El-Kheima. M. Sc. Thesis, Fac. of Sci., Ain Shams Univ., Cairo, Egypt.

Agrawal, S.C. (1999). Physical Factors Affecting the Flora. Limnology (1), 69-88.

Ali, E.M. and El Shehawy, A. (2017). Environmental indices and phytoplankton community structure as biological indicators for water quality of the River Nile, Egypt. Egypt. J. Aquat. Biol. Fish. 21: 87-104.

Ali, E.M. and Khairy, H.M. (2016). Environmental assessment of drainage water impacts on water quality and eutrophication level of Lake Idku, Egypt. Environ. Pollut. 216: 437-449.

Ali, E.M. and Khairy, H.M. (2012). Variations in phytoplankton carbon biomass, community assemblages and species succession along Lake Burullus, Northern Egypt. J. Environ. Biol. 33, 945.

Amin, A.S. (2007). Using of phytoplankton and physicochemical parameters as indicator of pollution in El-Timsah Lake, Ismailia, Egypt. Arts and Humanities. 17(3): 1-21.

Apha, A. (2012). Standard methods examination of water wastewater. $22^{\text {nd }}$ American Public Health Association (Eds.), Washington. 1360 pp.

Apha, A. (1998). Wef. Standard methods Examination of water wastewater 21, 1378.

AWC (2009). Middle East and North Africa Region/Arab Countries Regional Report. 5th World Water Forum, Istanbul. Arab Water Counc. (AWC), Egypt.

Azamuddin, A.; Ismail, A.; Che, S.; Rawi. and Syafalni, S. (2012). Integrating Biological Aspects into River Water Quality Research in Malaysia: An Opinion. OIDA Int. J. Sustain. Dev. 4: 107-122.

Baker, A.L. (2012). Phycokey-an image based key to Algae (PS Protista), Cyanobacteria, and other aquatic objects. University of New Hampshire Center for Freshwater Biology. http://cfb.unh.edu/phycokey/phycokey.htm 29 Dec 2019.

Barbour, M.T.; Gerritsen, J.; Snyder, B.D. and Stribling, J.B. (1999). Rapid bioassessment protocols for use in streams and wadeable rivers: periphyton, benthic macroinvertebrates and fish (Vol. 339). Washington, DC: US Environmental Protection Agency, Office of Water.

Barbour, M.T. and Yoder, C.O. (2000). The multimetric approach to bioassessment, 
as used in the United States of America. Assess. Biol. Qual. fresh waters RIVPACS other Tech. Proc. an Int. Work. held Oxford, UK, 16-18 Sept. 1997 (pp. 281-292).

Bellinger, E.G. and Sigee, D.C. (2015). Freshwater algae: identification, enumeration and use as bioindicators. John Wiley \& Sons. pp.1-40.

Chaturvedi, R.K.; Sharma, K.P.; Sharma, K.; Bhardwaj, S.M. and Sharma, S. (1999). Plankton community of polluted waters around Sanganer, Jaipur. J. Environ. Pollut. 6: 77-84.

Chessel, D. and Doledec, S. (1992). ADE Software (Version 3.6), multivariate Analyses and Graphical Display for Environmental Data. User's Man.

Clark, A.; Turner, T.; Dorothy, K.P.; Goutham, J.; Kalavati, C. and Rajanna, B. (2003). Health hazards due to pollution of waters along the coast of Visakhapatnam, east coast of India. Ecotoxicol. Environ. Saf. 56: 390-397.

El-hady, H.H.A. (2014). Alternations in biochemical structures of phytoplankton in Aswan Reservoir and River Nile , Egypt. J. Biodivers. Environ. Sci. 4: 68-80.

El-Hady, H.H.A. and Hussian, A.E.M. (2012). Regional and seasonal variation of phytoplankton assemblages and its biochemical analysis in Ismailia Canal, River Nile, Egypt. J. Appl. Sci. Res. 8: 3433-3447.

El-Manawy, I.M. and Amin, A.S. (2004). a Wintertime Blue-Green Algal Bloom in the Suez Freshwater Canal , Egypt. Egypt. J. Nat. Toxins 1: 135-152.

EWQS, E. (2007). Ministry of Health, drinking water quality standards, Population Decision number 458pp.

Geriesh, M.H.; Balke, K.D. and El-Rayes, A.E. (2008). Problems of drinking water treatment along Ismailia Canal Province, Egypt. J. Zhejiang Univ. Sci. B 9: 232-242. https://doi.org/10.1631/jzus.B0710634

Graham, L.E. and Wilcox, L.W. (2000). Cyanobacteria (chloroxybacteria). Algae. Upper Saddle River, New Jersey: Prentice Hall, pp. 97-131.

Grover, J.P.; Sterner, R.W. and Robinson, J.L. (1999). Algal growth in warm temperate reservoirs: nutrient-dependent kinetics of individual taxa and seasonal patterns of dominance. Arch. für Hydrobiol. 145 (1): 1-23.

Hill, B.H.; Herlihy, A.T.; Kaufmann, P.R.; Stevenson, R.J.; McCormick, F.H. and Johnson, C.B. (2000). Use of periphyton assemblage data as an index of biotic integrity. J. North Am. Benthol. Soc. 19: 50-67.

Hötzel, G. and Croome, R. (1999). A phytoplankton methods manual for Australian freshwaters. Land and Water Resources Research and Development Corporation Occasional Paper Series, 22, 99

Ibrahim, H.S.; Ibrahim, M.A. and Samhan, F. A. (2009). Distribution and bacterial bioavailability of selected metals in sediments of Ismailia Canal, Egypt. J. Hazard. Mater. 168: 1012-1016.

Karr, J.R.; Allan, J.D. and Benke, A.C. (2000). River conservation in the United States and Canada: Pages 3-38 in PJ Boon, BR Davies, and GE Petts, editors. Global perspectives on river conservation: science, policy, and practice.

Karyabwite, D.R. (2000). Water sharing in the Nile River valley. UNEP/ DEWA/Grid, Project GNV011: Using Gis. Remote Sensing for the sustainable use of natural resources. United Nations Environment Programme, Nairobi.

Kebede, E. and Ahlgren, G. (1996). Optimum growth conditions and light utilization efficiency of Spirulina platensis (Arthrospira fusiformis)(Cyanophyta) from Lake Chitu, Ethiopia. Hydrobiologia 332: 99-109.

NBI (2016). Nile Basin water resources atlas, Nile Basin Initiative (NBI). New Vis. Print. Publ. Co. Ltd 201. 
NWRC (2000). WL/DELFT Hydraulics. Natl. Water Resour. Plan Egypt, Water Qual. Pollut. Control. Tech. Rep. No. 5.

Prescott, A.G.W. (1978). Temperature and manganese as determining factor in the presence of diatoms or blue green algal flora in stream. Proc. Nat. Acad. 64: 472-478.

Shaaba, A.M.; Mansour, H.A. and Sabera, A.A.S. (2011). Relationship between total chlorophyll and phytoplankton individuals of Rosetta branch of River Nile, Egypt. Ecoprint An Int. J. Ecol. 18: 1-7.

Shaaban-Dessouki, S.A.; Deyab, M.A. and Mofeed, J. (2004). Phycological assessment of water quality of River Nile Delta- Egypt. Egypt. J. Phycol. 5: 1834.

Siliem, T.A.E. (1995). Primary productivity of the Nile in barrage area. Menofiya J. Agric. Res. 20 (4): 1687-1701.

Sobhy, E.H.M. (1999). Effects of industrial waste of Iron and steel Factories on Nile phytoplankton communities and productivity at Helwan (M.Sc. Fac. Sci.) Menia. Univ, 231pp.

Stahl, R. and Ramadan, A.B. (2008). Environmental studies on water quality of the Ismailia Canal/Egypt. Wissenschaftliche Berichte FZKA, 7427

Stahl, R.; Ramadan, A.B. and Pimpl, M. (2009). Bahr El-Baqar drain system/Egypt environmental studies on water quality. Part I: Bilbeis drain/Bahr El-Baqar drain. Wissenschaftliche Berichte FZKA, 7505.

Stevenson, R.J. and Pan, Y. (1999). Assessing environmental conditions in rivers and streams with diatoms. The diatoms: applications for the environmental and earth sciences, 1(4).

Sukumaran, P.K. (2002). Aquatic microflora in a perennial tank in Bangalore. Environ. Ecol. 20: 8-12.

Townsend, C.R.; Begon, M. and Harper, J.L. (2000). Essentials of ecology. Evol. Ecol. 8: 3-8.

Utermöhl, H. (1958). Zur vervollkommnung der quantitativen phytoplanktonmethodik: Mit 1 Tabelle und 15 abbildungen im Text und auf 1 Tafel. Int. Vereinigung für Theor. und Angew. Limnol. Mitteilungen. 9: 1-38.

Vaulot, D. (2001). Phytoplankton.Encyclopedia of Life Science. Macmillan Publishers Ltd. London, pp.1-7.

Weber, C. (1973). Biological field and laboratory methods for measuring the quality of surface waters and effluents (Vol. 73, No. 1). National Environmental Research Center, Office of Research and Development, US Environmental Protection Agency.

Wehr, J.D. (2003). RG Sheath (eds.)(2003). Freshwater Algae of North AmericaEcology and Classification, pp. 11-57.

Wetzel, R.G. and Likens, G.E. (1991). Limnological Analyses Springer-Verlag New York 391.

Wilks, D.S. (2011). Statistical methods in the atmospheric sciences (Vol. 100). Academic press.

Youssef, M.; El-Taweel, G.E.; El-Naggar, A.Y.; El-Hawary, S.E.; El-Meleigy, M.A. and Ahmed, S.A. (2010). Hydrocarbon degrading bacteria as indicator of petroleum pollution in Ismailia Canal, Egypt. World Appl. Sci. J. 8: 12261233. 